\title{
Madness and \\ marginality
}

The lives of

Kenya's White insane

\section{W I L L JACKS ON}




\section{IMPERIALISM}

general editor John M. MacKenzie

When the 'Studies in Imperialism' series was founded more than twenty-five years ago, emphasis was laid upon the conviction that 'imperialism as a cultural phenomenon had as significant an effect on the dominant as on the subordinate societies'. With more than ninety books published, this remains the prime concern of the series. Cross-disciplinary work has indeed appeared covering the full spectrum of cultural phenomena, as well as examining aspects of gender and sex, frontiers and law, science and the environment, language and literature, migration and patriotic societies, and much else. Moreover, the series has always wished to present comparative work on European and American imperialism, and particularly welcomes the submission of books in these areas. The fascination with imperialism, in all its aspects, shows no sign of abating, and this series will continue to lead the way in encouraging the widest possible range of studies in the field. 'Studies in Imperialism' is fully organic in its development, always seeking to be at the cutting edge, responding to the latest interests of scholars and the needs of this ever-expanding area of scholarship.

\section{Madness and marginality}

MANCHESTER 1824

Manchester University Press 
SELECTED TITLES AVAILABLE IN THE SERIES

\author{
RACE AND EMPIRE \\ Eugenics in colonial Kenya \\ Chloe Campbell \\ SCIENCE AND SOCIETY IN SOUTHERN AFRICA \\ Saul Dubow \\ REPRESENTING AFRICA \\ Landscape, exploration and empire in Southern Africa \\ John McAleer \\ ENDING BRITISH RULE IN AFRICA \\ Writers in a common cause \\ Carol Polsgrove \\ ORDERING AFRICA
}

Anthropology, European imperialism and the politics of knowledge

Helen Tilley (ed.) with Robert Gordon 


\title{
Madness and Marginality
}

\section{THE LIVES OF KENYA'S WHITE INSANE}

\author{
Will Jackson
}

MANCHESTER UNIVERSITY PRESS

Manchester and New York

distributed in the United States exclusively by

Palgrave Macmillan 
Copyright @ C Will Jackson 2013

The right of Will Jackson to be identified as the author of this work has been asserted by him in accordance with the Copyright, Designs and Patents Act 1988.

Published by MANCHESTER UNIVERSITY PRESS

OXFORD ROAD, MANCHESTER M13 9NR, UK

and ROOM 400, 175 FIFTH AVENUE, NEW YORK, NY 10010, USA

www.manchesteruniversitypress.co.uk

Distributed in the United States exclusively by

PALGRAVE MACMILLAN, 175 FIFTH AVENUE, NEW YORK, NY 10010, USA

Distributed in Canada exclusively by

UBC PRESS, UNIVERSITY OF BRITISH COLUMBIA,

2029 WEST MALL, VANCOUVER, BC, CANADA V6T $1 Z 2$

British Library Cataloguing-in-Publication Data

A catalogue record for this book is available from the British Library

Library of Congress Cataloging-in-Publication Data applied for

ISBN 9780719088896 hardback

First published 2013

The publisher has no responsibility for the persistence or accuracy of URLs for any external or third-party internet websites referred to in this book, and does not guarantee that any content on such websites is, or will remain, accurate or appropriate.

Typeset in Trump Medieval by

Koinonia, Manchester 